JURNAL PERSPEKTIF PENDIDIKAN

Vol 12 No 2 Desember 2018
P-ISSN 0216-9991

E-ISSN 2654-5004

\title{
TEACHING SPEAKING BY USING STORY COMPLETION \\ TECHNIQUE
}

\author{
Syaprizal, Gita Priska \\ STKIP PGRI Lubuklinggau, Indonesia
}

\begin{abstract}
ABSTRAK
These research conducted the answer question "was it significantly effective to teach speaking by using Story Completion Technique to the eighth grade students of SMP Muhammadiyah 1 Lubuklinggau." The objective of this research was to find out whether or not it is significantly effective to teach speaking by using Story Completion Technique to the eighth grade students of SMP Muhammadiyah 1 Lubuklinggau. The total population on this research was 145 students coming from 5 classes. The sample was taken by cluster random sampling. The sample of this research was VIII.3 as the sample with the total number of sample was 30 students. Based on the matched t-test calculation.It was found out that $t_{\text {obtain }}$ is 6.66 and the value or score of $t_{\text {table }} i$ is 1.699. the $t_{\text {obtain }}$ is higher than $t_{\text {table }}(6.66 \geq$ 1.699). It was found out the null hypothesis (HO) was rejected and the alternative hypothesis (Ha) was accepted. It means that it was significantly effective to teach speaking by using Story Completion Technique to the eighth grade students of SMP Muhammadiyah 1 Lubuklinggau in academic year of 2018/2019.
\end{abstract}

Kata Kunci: Teaching, Speaking, Story Completion.

\section{PENDAHULUAN}

Brown (2004:140),"speaking is a productive skill that can be directly and empirically observed". It is about carrying ideas in oral form to other which is considering people's perception anda process of understanding the message from the speaker. Learning language activity isgiven to students directly to express their feeling and communicate it, and share the ideas. Harmer (2007:343) states, speakers of English in range of diffeent genres especially where it is a second language will have to be able to speak in different situation and they need to be able in conveying the information. It is considered as an important aspect in communication to express and convey the ideas, meaning, information and one's thoughts in spoken language. In additional, Louma (2003:9), speaking as interaction in the social situation based on activity of people's daily life. it refers that speaking is one of productive skills in which, it is used to communicate with other.

http://ojs.stkippgri-lubuklinggau.ac.id/index.php/JPP 
According to Kayi (2006:2), "now many linguistics and English as Foreign Language (EFL) teachers agree on that students learn to speak in the second language by interacting".Communicative language teaching is based on real-life situations that require communication.In brief, EFL teachers should create a classroom environment where students have real-life communication, authentic activities, and meaningful tasks that promote oral language. Rather than leading students to pure memorization, providing a rich environment where meaningful communication takes place is desired. With this aim,speaking activities can contribute a great deal to students in developing basic interactive skills necessary for life.

Story completion is a creative technique that bring the students in free and enjoy activity in speaking class.

Based on Kayi (2006:4), story completion is very enjoyable and freespeaking activity for which students sit in a circle for this activity, a teacher starts to tell story, but after a few sentences he or she stops narrating. Then, each student starts to narrate from the point where the previous one stopped. Each student is supposed to add from four to ten sentences. Students can add new characters, events, description and so on.

Story completion is one of a new technique in teaching speaking which can increase the students' speaking skill. It might be caused by the reallife situation of the class which can make the students interested in following the lesson as who states that story completion is an activity which very enjoyable in whole class. The learners will easily be plunged into the plots of the story as they had to tell the part of the story decided. This technique helps students' speaking skills improving. Based on Kayi (2006:5), speaking through story completion technique as follows :

a. Teacher starts to tell a story.

b. The first speaker from a group students continue the story after the teacher stop narrating. Students start from the point on that previous one stooped.

c. Students should tell the idea of the story, so, the students will enjoy the speaking. 
d. Students should think about part of the story such as conflict in the story, climax until the resolution.

In this technique the sstudents should tell the idea of the story. so, the students will enjoy the speaking. Students should think about part of the story such as conflict in the story, climax until the resolution. Students can add new characters, events, description and so on. Researcher was conducted a research about "Teaching Speaking by Using Story Completion Technique to theEighth Grade students of SMPMuhammadiyah 1 Lubuklinggau."

\section{RESEARCH METHOD}

In this research,the researcher used Pre-Experimental design. The aim of the research was the researcher wanted to know the effectiveness of story completion technique in teaching speaking. Pre-Experimental Research also called as one shot case. The researcher used the one-group pretest-posttest design usually involves three steps : (1) administering a pretest measuring the dependent variable; (2) applying the experimental treatment $X$ to the subjects; (3) administering a posttest, again measuring the dependent variable.

In this research, story completion technique is the independent variable since, it influence to teaching speaking and the students achievement in speaking was dependent variable.

\section{Research variables:}

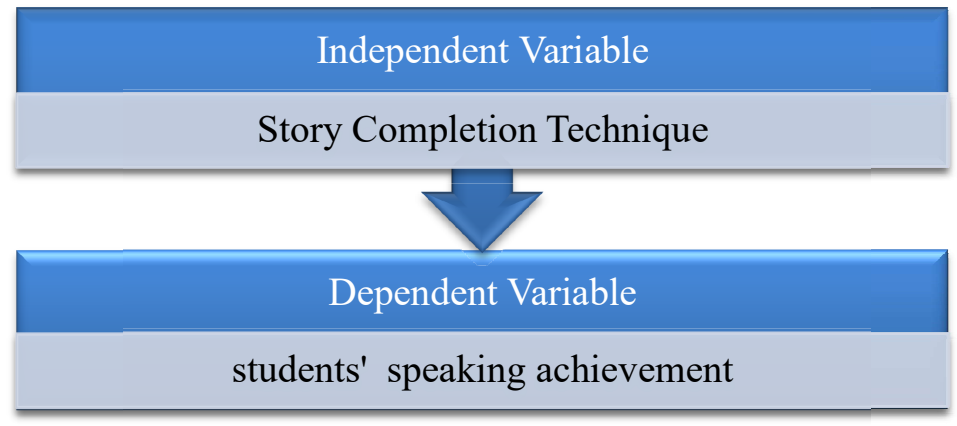

In this research, population were eighth grade students of SMP Muhammadiyah1 Lubuklinggau in academic year 2018/2019. There were 145 students coming from five classes as the population in this research. The sample http://ojs.stkippgri-lubuklinggau.ac.id/index.php/JPP 
of this research was VIII. 3 class. It was taken by cluster random sampling. The researcher wrote the classessin small piece of papers and the papers were rolled then the researcher chose among classess randomly and the sample was VIII. 3 consist of 30 students. In analyzing the data obtained from the test, the writer used there are fotechniques. They are: 1) Individual Score, 2) Conversion of individual score based on Minimum Mastery Criteria (MMC), 3) Normality test, and 4) Matched t-test.

\section{RESULT}

There were three results in this investigation: they were 1) the students' scores in the pre-test before treatment by using Story Completion Teachnique, and 2) the students' scores in the post-test after treatment, and 3) the result of the matched t-test calculation (the differences between the pre-test and the post-test score.

\section{The Students' Scores in the Pre-test}

The pre-test was given before the treatment in teaching speaking by using Story Completion Technique. After the test was given to the students, the researcher described the scores. The total number of the students who took the pre-test was 30 students. After tabulating the scores, it found out that the lowest score was 32 that was reached by 1 student and the highest score was 78 that was reached by 1 student. The average of the students' scores in the pre-test was 52.74 .

\section{The Students' Scores in the Post-Test}

The post-test was given after the treatment. the total number of the students who took the post-test was 30 students. After tabulating the score, it was found out that the lowest score was 42 reached by 1 student and the highest score was 82 reached by 1 student. The average score was 68.33 . 


\section{The Comparison Between the Students' Score in the Pre-test and Pos-test}

After giving the treatment by using Story Completion Technique, the students' score in English were better. It can be seen from the difference between the students' average score obtained in the pre-test and the post-test. In the pre-test the students' average score was 52.74 an the students' average in the post test was 68.33. It showed that there was significant difference between the average score in the pre-test and post-test. It means that the students' average in the post-test was higher than the students' average score in the pre-test

\section{Normality Testing}

The result of normality calculation in the pre-test and post-test (appendix B) was found that the degree of freedom freedom $(\mathrm{df})=(\mathrm{J}-1)=(6-1)$ with significance level 0.05 or $5 \%$. $\chi_{\text {table }}^{2}=\chi_{(1-\alpha)(j-1)}^{2}=\chi_{(0.95)(5)}^{2}=11.1$. The criteria for the normality test was if $\chi^{2}$ obtained $\leq \chi^{2}$ table, it could be concluded that the data was normal distributed.

\section{Pre-Test}

Before calculating the normality, the lowest score was 32 and the highest score was 78. From the result of normality calculation in the pre-test, it was found that the degree of freedom $(\mathrm{df})=(\mathrm{J}-1)=(6-1)$ with significance level 0.05 or 5 \%. $\chi_{\text {table }}^{2}=\chi_{(1-\alpha)(j-1)}^{2}=\chi_{(0.95)(5)}^{2}=11.1$. the criteria for the normality test was if $\chi^{2}$ obtained $\leq \chi^{2}$ table, it could be concluded that the data was normal distributed. In this

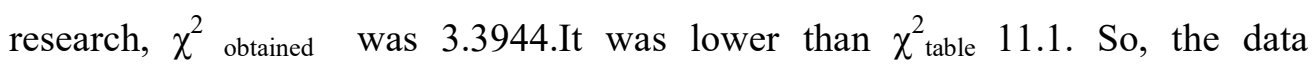
distribution of the pre-test could be considered as "normal".

\section{Post-Test}

In the post-test, after tabulating the score, it was found out that the lowest score was 42 and the highest score was 82 . From the result of normality calculation in the post-test, the degree of freedom $(\mathrm{df})=(\mathrm{J}-1)=(6-1)$ with significance level 0.05 or $5 \% . \chi_{\text {table }}^{2}=\chi_{(1-\alpha)(j-1)}^{2}=\chi_{(0.95)(5)}^{2}=11.1$. the criteria for the normality test was if $\chi^{2}$ obtained $\leq \chi^{2}$ table, it could be concluded that the data was http://ojs.stkippgri-lubuklinggau.ac.id/index.php/JPP 
normal distributed. In this research, $\chi^{2}$ obtained was 8.0649.It was lower than $\chi_{\text {table }}^{2}$ 11.1. So, the data distribution of the post-test could be considered as "normal".

\section{The Result of Matched T-Test Calculation}

Based on the matched t-test calculation (appendix B). It was found out that $t_{\text {obtain }}$ was 6.66 and the value or score of $t_{\text {table }}$ is 1.699. the $t_{\text {obtain }}$ was higher than $t_{\text {table }}(6.66 \geq 1.699)$. So, the alternative hypothesis was accepted. It means that it was significantly effective to teach speaking by using Story Completion Technique to the eighth grade students of SMP Muhammadiyah 1 Lubuklinggau in academic year of 2018/2019

\section{DISCUSSION}

After getting the data from the test, the researcher interpreted the result of the data analysis. As described above, the researcher found that after teaching speaking by Using Story Completion Technique, the sudents' achievement was increase. It could be seen from the difference between the students' average score in the pre-test and the post-test. In the pre-test, it was found out that the lowest score was 32 that was reached by 1 student and the highest score was 78 that was reached by 1 student. The average of the students' scores in the pre-test was 52.74 .

On the other hand, in the post-test, after tabulating the score, it was found out that the lowest score was 42 reached by 1 student and the highest score was 82 reached by 1 student. The average score was 68.33. It means that after treatment, the students' speaking skill were better by using Story Completion technique in teaching and learning process.

In the pre-test, the students still did some errors in grammars, pronounciation, and comprehension. And also, the students were lack of vocabularies. To solve those problems, the researcher gave some treatments by teaching speaking using Story Completion Technique. The treatments were given four times. The treatment process was began from divided them into five groups. Each group consist of 6 students incuded the chairman. The teacher asks the http://ojs.stkippgri-lubuklinggau.ac.id/index.php/JPP 
students to make circle and then the teacher gives differents story for each group. The chairman in each group as the main point to start the stroy and the story should be continued to the next member in that group. The story should be finished until the last member of that group. After the treatment was given to the all groups, the researcher gave the post-test to know the students' speaking skill.

According to Kayi (2006:4), story completion is free-speaking activity for which students sit in a circle for this activity, a teacher starts to tell story, but after a few sentences he or she stops narrating. Then, each student starts to narrate from the point where the previous one stopped. In addition, Story completiontechnique helps students' speaking skill improve,increase students' willingness to communicate thoughts and feelings, encourage active participation, increaseencourage use of imagination and creativity and encourage cooperation between students(Ghiabi, 2014:23).

Having done the treatment, the researcher administered the post-test. It could be concluded that the students speaking skill was increased, it could be seen by the average of students' speaking skill in the pre-test and in the post-test calculation. The average of students pre-test was 52.74 and in post-test the average was 68.33 . beside that it could be proved by the result of macthed t-test calculation. Based on the matched t-test calculation (appendix B). It was found out that $t_{\text {obtain }}$ is 6.66 and the value or score of $t_{\text {table }}$ is 1.699 . the $t_{\text {obtain }}$ is higher than $t_{\text {table }}(6.66 \geq 1.699)$. So, the alternative hypothesis is accepted. It means that it was significantly effective to teach speaking by using Story Completion Technique to the eighth grade students of SMP Muhammadiyah 1 Lubuklinggau in academic year of 2018/2019

\section{CONCLUSION}

Based on the finding and discussion, the researcher conculded that it was significantly effective to teacher spaeking by using Story Completion Technique to the eighth grade students of SMP Muhammadiyah 1 Lubuklinggau in the academic year of 2018/2019. It could be proved that there was improvement of the 
average scores from the pre-test (52.74) to the post-test (68.33) and their average ability changed from failed based on the minimum mastery criteria to be mastered

\section{REFERENCES}

Alqahtani, M. (2015). The important of vocabulary in learning language and how to be taught. International Journal of Teaching and Education,3(3), 1-14.

Ashdag, M.R. (2015). The Use of Story Completion Technique toImprove Students' Speaking Ability ofInternational Class Program BoardingStudents of Teacher Training and EducationFaculty of State Institute For Islamic StudiesSalatiga Batch. Salatiga: IAIN University.

Brown, H.D. (2004). language assessment principle and classroom practice. New York,San Fransisco State: Longman

Brown, H.D. (2000). Principles of language learning and teaching ( $4^{\text {th }}$ ed). New York, San Fransisco State University: Longman.

Clarke, V., Hayfield, N., Moller, N.,and Tischner, I. (2017).Successful qualitative research: APractical guide for beginners. New York: Cambrige University.

Fraenkel, J.R and Wallen, N.E. (2008). How to design and evaluate research in education $\left(7^{\text {th }}\right.$ ed). New York, San Fransisco: McGraw-Hill.

Fraenkel, J.R and Wallen, N.E. (2001). How to design and evaluate research in education $\left(8^{\text {th }}\right.$ ed). New York, San Fransisco: McGraw-Hill.

Gilbert, B.J. (2008). Teaching pronunciation using the porody pyramid. New York: Cambrige University.

Ghiabi, S. (2014). Investigating the effects of story retelling technique as aclosed task vs. story completion technique as an open task on efllearner's speaking.International Journal of English and Education,3(3), 17-25.

Hatch, E and Farhady, H. (1982). Research design and statistic for applied linguistics. Cambridge: Newbury house publisher.

Harmer, J. (2007). The practice of english language and teaching $\left(4^{\text {th }} \mathrm{ed}\right)$. England Pearson.

Hartwell, P. (2008). Grammar, grammars and teaching of grammar. National council of teacher of english,2(4), 105-127. 
Kayi, H. (2006). Teaching speaking: Activities to promote speaking in a second language.Teaching English as Second Language, 11(12), 1-9.

Latief, M.A. (2014). Research methods on language learning an introduction. Malang: Universitas Negeri Malang.

Louma, S. (2003). Assessing speaking. United Kingdom: Cambridge University

Nguyen. (2015). The key principles for development speaking. International Journal on Studies in English Language and Literature, 1(3), 49-53.

O'sullivan, B. (2008). Notes on assessing speaking. Retrievied from: https://www.Irc.cornell.edu/events/past/2008-2009/papers08/ossull.

Priyana, P., Irjayanti, A.R., and Renitasari, V. (2008). Scaffolding english for junior high school grade VIII. Jakarta: Departemen Pendidikan Nasional.

Sequeira, A.H. (2012). Introduction of concept in teaching and learning. India: National Institute of Technology Karnataka.

Solcova, P. (2011). Teaching Speaking: English language and literature. Ausrtie: Masaryk University.

Subana and Sudrajat. (2009). Dasar-dasar penelitian ilmiah. Bandung: Pustaka Ilmiah.

Sudjana. (2013). Metoda statistika. Bandung: Tarsito.

Sudijono, A. (2012). Pengantar statistik pendidikan. Jakarta: Rajawali pers. 